\title{
PENGARUH MEDIA PEMBELAJARAN EXE (ELEARNING XHTML EDITOR) TERHADAP HASIL BELAJAR KONSTRUKSI BANGUNAN KOMPETENSI KEAHLIAN TEKNIK GAMBAR BANGUNAN PADA SISWA KELAS X SMK NEGERI 5 MEDAN
}

\author{
Sadzali Yunaifi Machril ${ }^{1}$, Darwin ${ }^{2}$ \\ ${ }^{1}$ Alumni Program Studi Pendidikan Teknik Bangunan, Fakultas Teknik UNIMED \\ ${ }^{2}$ Dosen Pengajar Jurusan Pendidikan Teknik Bangunan, Fakultas Teknik UNIMED \\ (Darwin@gmail.com)
}

\begin{abstract}
ABSTRAK
Penelitian yang digunakan dalam penelitian ini adalah Kuasi Eksperimen. Penelitian ini bertujuan untuk mengetahui berapa besar pengaruh media pembelajaran EXE (Elearning XHTML Editor) terhadap hasil belajar Konstruksi Bangunan siswa kelas X SMK Negeri 5 Medan. Sampel penelitian ini adalah seluruh siswa kelas $\mathrm{X}$ jurusan teknik gambar bangunan dengan jumlah sampel sebanyak 66 orang dan cara pemilihan kelas secara acak. Kemudian didapat kelas X TGB-1 sebagai kelas eksperimen dan kelas X TGB-2 sebagai kelas kontrol. Alat pengumpulan data menggunakan tes pilihan berganda sebanyak 22 soal yang diuji cobakan terlebih dahulu. Sebelum adanya perlakuan, kelas diberikan pre-test untuk mengetahui kemampuan awal siswa, kemudian setelah adanya perlakuan diberikan Post-test untuk memperoleh data hasil belajar sebagai alat pengumpulan data penelitian. Hasil penelitian menunjukkan bahwa hasil belajar Konstruksi Bangunan yang diajar dengan media pembelajaran EXE (Elearning XHTML Editor) lebih besar dari yang diajar dengan pembelajaran konvensional. Hal ini dibuktikan dengan pengujian hipotesis untuk $t_{\text {hitung }}=2,263$ dan $t_{\text {tabel }}$ yang diperoleh berdasarkan interpolasi pada taraf $\alpha=0,05$ adalah 1,67. Karena $t_{\text {hitung }}>t_{\text {tabel, }}$ maka $\mathrm{H}_{\mathrm{o}}$ ditolak dan $\mathrm{H}_{\mathrm{a}}$ diterima. Dapat disimpulkan bahwa pembelajaran elearning memberi pengaruh yang berbeda secara signifikan tehadap hasil belajar Konstruksi Bangunan Kelas X SMK Negeri 5 Medan.
\end{abstract}

Kata Kunci : Media Pembelajaran, EXE, Hasil Belajar, Konstruksi Bangunan

\section{ABSTRACT}

Research used in this study is Quasi Experiment. This study aims to determine how much influence the media EXE learning (eLearning XHTML editor) on learning outcomes Building Construction class X SMK Negeri 5 Medan. Samples were all students of class X engineering drawings with a total sample of 66 people and the way randomly selecting classes. Then obtained a class X TGB-1 as an experimental class and class X TGB-2 as the control class. Means of data collection using a multiple-choice test with 22 questions that tested beforehand. Prior to the treatment, the class was given a pre-test to determine the ability of the student early, then after the treatment was given post-test to obtain data on learning outcomes as a means of data collection research. The results showed that the learning outcomes of Building Construction taught by instructional media EXE (eLearning XHTML editor) is greater than that taught by conventional learning. This is proven by testing the hypothesis for $t=2.263$ and ttable obtained by interpolation on the level of $a=0.05$ is 1.67. Because $t$ count $>t$ table, then $\mathrm{Ho}$ is rejected and $\mathrm{Ha}$ accepted. It was concluded that the learning elearning different influences significantly tehadap learning outcomes Building Construction Class X SMK Negeri 5 Medan.

Keywords: Learning Media, EXE, Learning Outcomes, Building Construction 


\section{Pendahuluan}

Perkembangan ilmu pengetahuan dan teknologi semakin mendorong upaya-upaya pembaharuan dalam pemanfaatan hasil-hasil teknologi dalam proses belajar. Para guru dituntut agar mampu menggunakan alat-alat yang dapat disediakan oleh sekolah, dan tidak menutup kemungkinan bahwa alat-alat tersebut sesuai dengan perkembangan dan tuntutan zaman. Guru sekurang-kurangnya dapat menggunakan alat yang murah dan efisien yang meskipun sederhana dan bersahaja tetapi merupakan keharusan dalam upaya mencapai tujuan pengajaran yang diharapkan. Di samping mampu menggunakan alat-alat yang tersedia, guru juga dituntut untuk dapat mengembangkan keterampilan membuat media pembelajaran yang akan digunakannya apabila media tersebut belum tersedia. Salah satu pemanfaatan teknologi, informasi dan komunikasi dalam dunia pendidikan adalah penggunaan media pembelajaran interaktif berbasis komputer. Menurut Gayestik yang dikutip oleh Sunaryo Soenarto (2009), media pembelajaran interaktif adalah sistem komunikasi efektif berbasis komputer yang mampu menciptakan, menyimpan, menyajikan dan mengakses kembali informasi berupa teks, suara, video atau animasi. Komputer juga mampu membawa permasalahan dunia nyata yang tidak mungkin dihadirkan di kelas dengan media konvensional melalui teknik simulasi.

Salah satu aplikasi komputer yang dapat digunakan guru dalam menyusun media pembelajaran adalah dengan menggunakan $e X e$ (eLearning XHTML editor). Program aplikasi ini merupakan suatu open source yang mudah digunakan baik oleh orang yang tidak mengerti bahasa pemograman sekalipun.

Berdasarkan observasi awal di SMK Negeri 5 Medan, terdapat permasalahan yang dihadapi dalam pelaksanaan pembelajaran pada mata pelajaran Konstruksi Bangunan. Peneliti menemukan bahwa hasil belajar siswa Kelas X Program Keahlian Teknik Gambar Bangunan Tahun Pelajaran 2012/2013 dan 2013/2014 masih terdapat beberapa siswa yang tidak kompeten, mengingat bahwa Kriteria Ketuntasan Minimal (KKM) di SMK Negeri 5 Medan yaitu 70. Hal ini dapat dilihat melalui persentase hasil belajar siswa kelas $\mathrm{X}$ pada mata pelajaran Konstruksi Beton Bertulang Semester Ganjil berikut:

Tabel 1. Hasil nilai mata pelajaran Konstruksi Beton Bertulang Program Keahlian Teknik Gambar Bangunan Kelas X SMK Negeri 5 Medan

\begin{tabular}{|c|c|c|c|c|}
\hline TA & Nilai & $\begin{array}{c}\text { Jlh } \\
\text { Siswa }\end{array}$ & $\begin{array}{c}\text { Persentase } \\
(\%)\end{array}$ & Ket \\
\hline \multirow{4}{*}{$\begin{array}{c}2012 \\
/ 201 \\
3\end{array}$} & $<70$ & 9 & 32,14 & $\begin{array}{c}\text { Tidak } \\
\text { Kompeten }\end{array}$ \\
\hline & $\begin{array}{c}70- \\
79\end{array}$ & 10 & 35,72 & $\begin{array}{c}\text { Cukup } \\
\text { Kompeten }\end{array}$ \\
\hline & $\begin{array}{c}80- \\
89\end{array}$ & 9 & 32,14 & Kompeten \\
\hline & $\begin{array}{c}90- \\
100\end{array}$ & 0 & 0 & $\begin{array}{c}\text { Sangat } \\
\text { Kompeten }\end{array}$ \\
\hline & lah & 28 & 100 & \\
\hline \multirow{4}{*}{$\begin{array}{c}2013 \\
/ 201 \\
4\end{array}$} & $<70$ & 3 & 10,71 & $\begin{array}{c}\text { Tidak } \\
\text { Kompeten }\end{array}$ \\
\hline & $\begin{array}{c}70- \\
79\end{array}$ & 5 & 17,86 & $\begin{array}{l}\text { Cukup } \\
\text { Kompeten }\end{array}$ \\
\hline & $\begin{array}{c}80- \\
89\end{array}$ & 18 & 64,29 & Kompeten \\
\hline & $\begin{array}{l}90- \\
100\end{array}$ & 2 & 7,14 & $\begin{array}{c}\text { Sangat } \\
\text { Kompeten }\end{array}$ \\
\hline \multicolumn{2}{|c|}{ Jumlah } & 28 & 100 & \\
\hline
\end{tabular}

Hasil belajar siswa seperti yang tertera pada tabel 1 . menunjukkan beberapa siswa yang sudah kompeten sebesar $67,86 \%$ pada tahun pelajaran 2012/2013 dan $89,29 \%$ pada tahun pelajaran 2013/2014. Sedangkan beberapa siswa masih mengalami kesulitan dalam memahami mata pelajaran Konstruksi Bangunan. Dapat dilihat bahwa pada Tahun Pelajaran 2012/2013 terdapat 32,14\% yang tidak kompeten sedangkan pada Tahun Pelajaran 2013/2014 terdapat $10,71 \%$ yang tidak kompeten.

Melalui media pembelajaran ini kita akan dapat mengetahui pengaruh media pembelajaran melalui eXe (eLearning XHTML editor) terhadap hasil belajar Konstruksi Bangunan siswa kelas X SMK Negeri 5 Medan

\section{Kajian Pustaka}

\subsection{Hakikat Hasil Belajar}

Belajar diartikan sebagai dari yang tidak tahu menjadi tahu, dari yang tidak paham menjadi paham, dari yang tidak mampu menjadi mampu dan seterusnya. Belajar merupakan suatu usaha yang ditandai dengan adanya rasa ingin tahu seseorang terhadap 
pengalaman baru. Belajar merupakan suatu proses pengembangan pola pikir, yang prosesnya didapat melalui anggapan dan informasi serta memanfaatkan informasi tersebut untuk memecahkan masalah yang ditemui. Belajar merupakan suatu kejadian yang terjadi secara sengaja oleh orang yang terlibat di dalamnya. Belajar adalah suatu proses yang ditandai dengan adanya perubahan pada diri seseorang (Sabri, 2010). Menurut Hamalik (2008) belajar merupakan suatu proses, suatu kegiatan dan bukan suatu hasil atau tujuan. Belajar bukan hanya mengingat, akan tetapi lebih luas dari itu, yaitu pengalaman. Belajar bukan suatu penguasaan hasil latihan melainkan perubahan kelakuan.

Hasil belajar merupakan sejumlah bukti terjadinya perubahan tingkah laku pada diri seseorang, misalnya suatu perubahan dari tidak tahu menjadi tahu dan tidak mengerti menjadi mengerti (Hamalik, 2008). Tingkah laku manusia terdiri dari beberapa aspek dan hasil belajar, yang akan terlihat dari setiap perubahan aspek-aspek tersebut seperti aspek pengetahuan, aspek pengertian, aspek kebiasaan, aspek keterampilan, aspek apresiasi, aspek emosional, aspek hubungan sosial, aspek jasmani, aspek budi pekerti dan terakhir aspek sikap. Seorang guru harus mempunyai kemampuan untuk mengetahui terjadinya perubahan tingkah laku tersebut setelah malakukan penelitian.

Menurut Sudjana dalam Noviyanti (2013 : 12), hasil belajar siswa pada hakikatnya adalah perubahan tingkah laku. Tingkah laku sebagai hasil belajar dalam pengertian yang luas mencakup bidang kognitif, afektif dan psikomotorik. Sehingga hasil belajar merupakan ukuran atau standar kepada peserta didik guna melihat perubahan kemampuan peserta didik dalam bidang kognitif (pengetauan), afektif (sikap) dan psikomotorik (keterampilan).

Untuk mengetahui sejauh mana pengetahuan siswa terhadap materi yang diajarkan dapat dilihat dari hasil belajar siswa, yang umumnya diperolah dari hasil tes yang dilakukan setelah selesai melaksanakan kegiatan belajar. Menurut Purwanto (2010: 45), hasil belajar adalah perubahan yang mengakibatkan manusia berubah dalam sikap dan tingkah lakunya. Dari defenisi di atas maka dapat disimpulkan bahwa hasil belajar merupakan hasil yang terlihat dan tertulis kedalam sebuah penilaian sesuai dengan kemampuan yang dimiliki seorang siswa setelah menerima pelajaran yang diberikan oleh guru. Penilaian terhadap hasil belajar sangat penting karena dapat memberikan informasi kepada guru mengenai ketercapaian tujuan belajar melalui proses belajar.

\subsection{Hakikat Media Pembelajaran}

Kata media berasal dari bahasa latin, yaitu medius yang secara harfiah berarti tengah, perantara atau pengantar. Menurut Gerlach dan Ely (1971) mengatakan bahwa media apabila dipahami secara garis besar adalah manusia, materi atau kejadian yang mambangun kondisi yang membuat siswa mampu memperoleh pengetahuan, ketrampilan atau sikap. Dalam pengertian ini, guru, buku teks dan lingkungan sekolah merupakan media. Secara lebih khusus, pengertian media dalam proses belajar mengajar cenderung diartikan sebagai alat-alat grafis, photografis atau elektronis untuk menangkap, memproses dan menyusun kembali informasi visual atau verbal.

Heinich dan kawan-kawan mengemukakan istilah medicium sebagai perantara yang mengatur informasi antara sumber dan penerima. Jadi, televise, film, foto, radio, rekaman audio, gambar yang diproyeksikan, bahan-bahan cetakan dan sejenisnya adalah media komunikasi. Apabila media itu membawa pesan-pesan atau informasi yang bertujuan instruksional atau mengandung maksud-maksud pengajaran maka media itu disebut media pembelajaran.

Acapkali kata media pendidikan digunakan secara bergantian dengan istilah alat bantu atau media komunikasi seperti yang dikemukakan oleh Hamalik (1986), dimana ia melihat bahwa hubungan komunikasi akan berjalan lancar dengan hasil yang maksimal apabila menggunakan alat bantu yang disebut media komunikasi. Sementara itu, Gagne' dan Briggs (1975) secara implisit mengatakan bahwa media pembelajaran meliputi alat yang secara fisik digunakan untuk menyampaikan isi materi pengajaran, yang terdiri antara lain buku, tape recorder, kaset, video kamera, video recorder, film, slide (gambar bingkai), foto, gambar, grafik, televisi dan komputer. Dengan kata lain, media adalah komponen sumber belajar atau wahana fisik yang mengandung 
materi instruksional di lingkungan siswa yang dapat merangsang siswa untuk belajar.

Berdasarkan uraian di atas, media pembelajaran dapat dipahami sebagai segala sesuatu yang dapat menyampaikan dan menyalurkan pesan dari sumber secara terencana sehingga tercipta lingkungan belajar yang kondusif di mana penerimanya dapat melakukan proses belajar secara efisien dan efektif.

\subsubsection{Desain Pembelajaran (ELearning XHTML Editor)}

EXE

Pembelajaran melalui eXe (eLearning XHTML editor) adalah pembelajaran yang menggunakan komputer dalam merencanakan dan melaksanakan aktivitas belajar mengajar yang dilengkapi dengan beberapa perangkat lunak (software) yang ditampilkan melalui sebuah media berbasis web. Jenis software yang biasa digunakan dalam media pembelajaran berbasis eLearning ini adalah Macromedia Dreamweaver 8, Notepad ++, eXe (eLearning XHTML editor) dalam bentuk CD dengan sifat software development animasi dan open source.

Adapun yang menjadi keunggulan dalam penggunaan desain $e X e$ ini adalah: mudah digunakan walaupun tidak mengetahui bahasa pemograman HTML; WYSIWYG (What You See Is What You Get), sehingga memudahkan dalam perancangan karena apa yang terlihat di layar akan sama dengan hasil akhir bila dijalankan (dipublikasikan); standar eLearning (SCORM) dan dapat digunakan pada sistem operasi Windows maupun Linux.

Adapun proses pembuatan media pembelajaran eXe (eLearning XHTML editor) tersebut adalah: (1) membuat kerangka dasar; (2) membuat halman awal eLearning berbasi web; (3) mengelola gambar, audio dan video; (4) membuat bahan ajar; (5) membuat soal-soal interaktif; dan (6) menyimpan file atau mengunggah file ke free web hosting yang tersedia di internet sehingga dapat diakses oleh siswa dalam pembelajaran nantinya. Berikut disajikan gambar hasil rancangan pembelajaran eLearning.

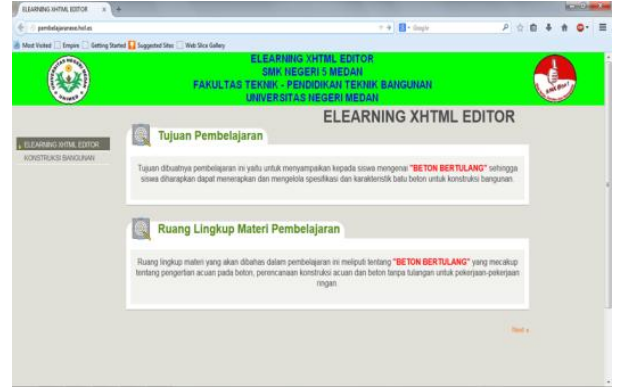

Gambar 1. Tampilan Awal Fitur Pembelajaran

Pada tampilan awal ini, tersedia fiturfitur pembelajaran yang terdiri atas fitur panduan, materi, latihan dan evaluasi pembelajaran. Fitur ini merupakan bagian dari rancangan pembelajaran ini

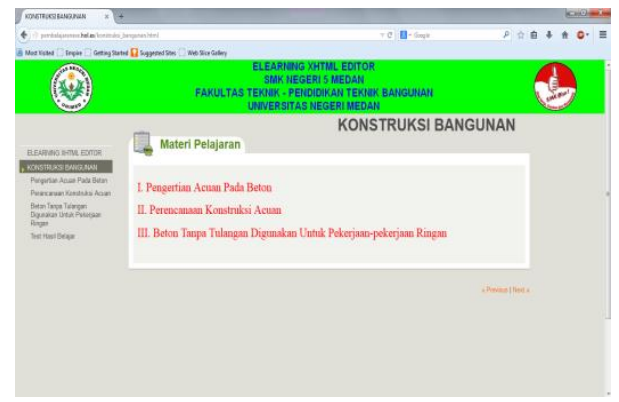

Gambar 2. Tampilan Fitur Materi Pelajaran

Fitur ini menyajikan materi pelajaran secara lengkap sebagai inti dari rancangan pembelajaran. Melalui fitur ini, siswa dapat memahami materi pelajaran Konstruksi Bangunan.

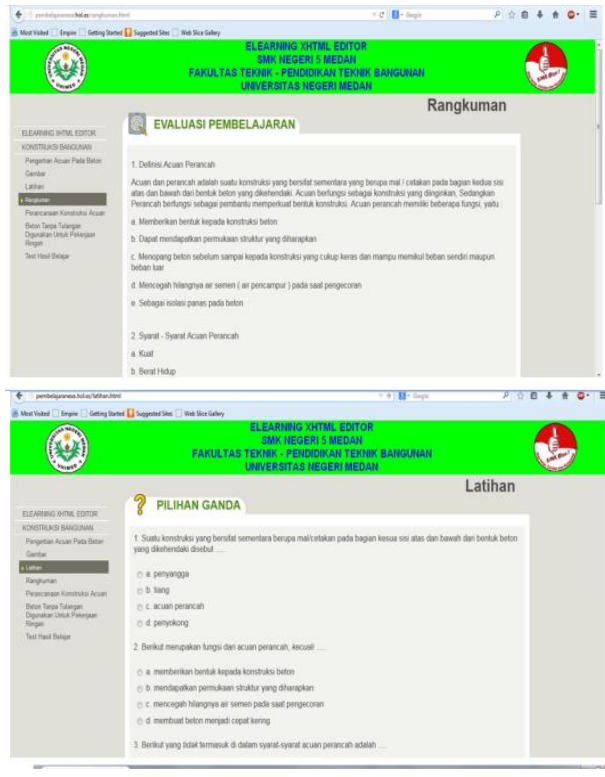


Gambar 3. Tampilan Fitur Evaluasi Pemebelajaran

\subsection{Hakikat Pembelajaran Konvensional}

Dalam pembelajaran yang dilaksanakan cenderung berpusat pada guru dalam merancang dan mengimplementasikan program pembelajaran sehingga peran guru sangat dominan dalam kegiatan pembelajaran. Guru akan lebih banyak memberikan informasi-informasi sedangkan siswa sebagai pendengar yang secara seksama akan merekam dan menyimak penjelasan yang diberikan guru. Hal ini sesuai dengan yang dinyatakan oleh Sudjana (2001 : 39-40) bahwa melalui pembelajaran konvensional peserta didik mendapatkan informasi yang lebih rinci dari guru dan bahan belajar dapat disampaikan secara tuntas. Sedangkan menurut Djamarah (1996), metode pembelajaran konvensional adalah metode pembelajaran tradisional atau disebut juga dengan metode ceramah, karena sejak dulu metode ini telah

dipergunakan sebagai alat komunikasi lisan antara guru dengan anak didik dalam proses belajar dan pembelajaran. Dalam pembelajaran sejarah metode konvensional ditandai dengan ceramah yang diiringi dengan penjelasan, serta pembagian tugas dan latihan.

\section{Metodologi Penelitian}

Penelitian ini dilaksanakan di SMK Negeri 5 Medan untuk kelas X Kompetensi Keahlian Teknik Gambar Bangunan. Sementara waktu pelaksanaan penelitian ini dilakukan mulai pada bulan Februari 2015 sampai dengan selesai

Populasi dalam penelitian ini adalah seluruh siswa kelas X jurusan Teknik Gambar Bangunan SMK Negeri 5 Medan sebanyak 2 kelas, dengan jumlah 66 orang dengan rincian sebagai berikut:

Tabel 2. Populasi Penelitian

\begin{tabular}{ccc}
\hline Kelas & X TGB-1 & X TGB-2 \\
\hline Jumlah & 33 orang & 33 orang \\
\hline
\end{tabular}

Sampel penelitian dibutuhkan dua kelas, maka sampel diambil dua kelas secara acak, karena semua kelas mempunyai peluang yang sama untuk menjadi objek penelitian yang akan benar-benar diteliti.

Dengan mengundi secara acak, maka kelas $X$ TGB-1 sebagai kelompok yang diberi perlakuan penerapan dengan media pembelajaran eXe (eLearning XHTML editor) $\left(\mathrm{X}_{1}\right)$ dan kelas $X$ TGB-2 sebagai kelompok yang diberi perlakuan penerapan dengan pembelajaran berbasis konvensional $\left(X_{2}\right)$.

Tabel 3. Sampel Penelitian

\begin{tabular}{cccl}
\hline No & $\begin{array}{c}\text { Kelompok } \\
\text { Penelitian }\end{array}$ & $\begin{array}{c}\text { Jumlah } \\
\text { Siswa }\end{array}$ & $\begin{array}{c}\text { Jenis } \\
\text { Perlakuan }\end{array}$ \\
\hline 1 & $\mathrm{X}_{1}$ & 33 & $\begin{array}{l}\text { Diberikan } \\
\text { pembelajaran } \\
\text { eXe (eLearning } \\
\text { XHTML editor }) \\
\text { Diberikan } \\
\text { pembelajaran } \\
\end{array}$ \\
& $\mathrm{X}_{2}$ & 33 & $\begin{array}{l}\text { berbasis } \\
\text { konvensional }\end{array}$ \\
\hline
\end{tabular}

\subsection{Teknik Pengumpulan Data}

Pengumpulan data dilakukan dengan menggunakan tes objektif untuk data hasil belajar mata pelajaran Konstruksi Bangunan. Langkah penyusunan instrumen penelitian berdasarkan konsep dan teori yang diuraikan terlebih dahulu, kemudian dirumuskan ke dalam bentuk defenisi operasional yang kemudian dijabarkan dalam bentuk kisi-kisi. Dari kisi-kisi tersebut kemudian dibuat menjadi butir-butir soal berupa pertanyaan.

Tabel 4. Tes objektif untuk data hasil belajar mata pelajaran Konstruksi Bangunan

\begin{tabular}{|c|c|c|c|c|c|}
\hline \multirow{2}{*}{$\begin{array}{c}\mathbf{N} \\
\mathbf{0}\end{array}$} & \multirow{2}{*}{ Indikator } & \multicolumn{3}{|c|}{ Klasifikasi/kategori } & \multirow{2}{*}{$\begin{array}{c}\text { Jlh } \\
\text { Soal }\end{array}$} \\
\hline & & $\mathrm{C}_{1}$ & $\mathrm{C}_{2}$ & $\mathrm{C}_{3}$ & \\
\hline 1 & $\begin{array}{l}\text { Pengertian } \\
\text { Acuan Pada } \\
\text { Beton }\end{array}$ & $\begin{array}{l}1,4, \\
25\end{array}$ & $\begin{array}{l}2,3,5 \\
6,7\end{array}$ & & 8 \\
\hline 2 & $\begin{array}{l}\text { Perencanaan } \\
\text { Konstruksi } \\
\text { Acuan }\end{array}$ & 9 & 8 & $\begin{array}{l}10,11, \\
12,13, \\
14,15, \\
16,17, \\
18,19\end{array}$ & 12 \\
\hline 3 & $\begin{array}{l}\text { Beton Tanpa } \\
\text { Tulangan } \\
\text { Digunakan } \\
\text { Untuk } \\
\text { Pekerjaan } \\
\text { Ringan }\end{array}$ & $\begin{array}{l}20,21 \\
22,24\end{array}$ & 23 & & 5 \\
\hline & & lah Soal & & & 25 \\
\hline
\end{tabular}

\subsection{Hasil Uji Coba Instrumen}

Instrumen hasil belajar Konstruksi Bangunan dijaring dengan menggunakan test berbentuk objektif yang terdiri dari Pre Test (sebelum perlakuan) dan Post Test (setelah 
perlakuan) dengan bentuk soal yang berbeda tetapi dengan tingkat kesulitan yang sama. Penggunaan test objektif ini berdasarkan kepada pertimbangan tentang ciri dan kemampuan, objektifitas, penilaian, keluasan dan keragaman materi pelajaran yang akan ditanyakan serta kemudahan kemudahan administrasi penilaian (Arikunto, 2006). Setiap butir test pilihan berganda terdiri dari empat pilihan jawaban, dengan bobot nilai untuk setiap jawaban benar diberi nilai 1 (satu) dan untuk setiap jawaban salah diberi nilai 0 (nol).

Berdasarkan hasil uji coba instrument yang telah diakukan sebelumnya, didapat sebanyak 3 butir soal yang dinyatakan gugur, yaitu butir soal nomor 15, 17 dan 25. Untuk reliablitas didapat $\mathrm{r}_{11}$ sebesar 0,990 . Setelah dikonsultasikan dengan indeks korelasi, reliabilitas tes secara keseluruhan tersebut termasuk dalam kategori sangat tinggi. Untuk tingkat kesukaran 2 soal dengan kategori sedang dan 20 soal dengan kategori mudah. Sedangkan daya pembeda soal diperoleh 5 soal dengan kategori baik dan 17 soal dengan kategori cukup. Dengan demikian soal yang dipakai untuk menjaring data dalam penelitian ada 22 butir soal.

\section{Hasil Penelitian dan Pembahasan}

\subsection{Data Pre Test Hasil Belajar Konstruksi}

\section{Bangunan Kelas Eksperimen}

Pada tahapan penelitian, kedua sampel yaitu kelas eksperimen dan kelas kontrol diberikan pre test yang bertujuan melihat kemampuan awal siswa pada kedua kelas tersebut. Nilai yang diperoleh siswa kelas eksperimen menggunakan media pembelajaran eXe berbasis elearning dapat dilihat pada tabel berikut.

Tabel 5. Data Pre Test hasil Belajar Konstruksi Bangunan Kelas Eskperimen

\begin{tabular}{lc}
\hline Rata-rata & 67,36 \\
\hline Nilai Tertinggi & 86 \\
\hline Nilai Terendah & 45 \\
\hline Standar Deviasi & 12,42 \\
\hline Varians & 154,256 \\
\hline
\end{tabular}

Berdasarkan data hasil pre test diperoleh dengan jumlah responden 33 siswa, terdapat nilai tertinggi $=86$ dan nilai terendah $=45$ dengan rata-rata $(M)=67,36$ dan standar deviasi $(\mathrm{St})=12,42$. Dengan menggunakan teknik sturges didapatkan banyak kelas 5 dan panjang kelas 9, dan dimulai dengan ujung bawah kelas pertama yaitu 45 .
Berdasarkan data yang diperoleh pada pre test kelas eksperimen, maka dapat diperoleh tingkat kecenderungan pada tabel berikut:

Tabel 6. Data Tingkat Kecendrungan Pre Test hasil Belajar Konstruksi Bangunan Kelas Eskperimen

\begin{tabular}{cccc}
\hline $\begin{array}{c}\text { Kelompok } \\
\text { Interval }\end{array}$ & $\begin{array}{c}\text { F. } \\
\text { Absolut }\end{array}$ & $\begin{array}{c}\text { F. } \\
\text { Relatif }\end{array}$ & Kategori \\
\hline $75,745<$ & 12 & $36,36 \%$ & Tinggi \\
$65,5 \leq x<75,745$ & 4 & $12,12 \%$ & Cukup \\
$55,255 \leq x<65,5$ & 10 & $30,30 \%$ & Kurang \\
$<55,255$ & 7 & $21,21 \%$ & Rendah \\
\hline Jumlah & 33 & $100 \%$ & \\
\hline
\end{tabular}

Berdasarkan perhitungan di atas diperoleh bahwa pre test tes hasil belajar Konstruksi Bangunan pada kelas eksperimen mempunyai tingkat kecenderungan yang tinggi.

\subsection{Data Pre Test Hasil Belajar Konstruksi Bangunan Kelas Kontrol}

Berdasarkan tes hasil belajar yang diberikan sebelum proses pemberian perlakuan, nilai yang diperoleh siswa pada kelas kontrol atau yang akan diajarkan dengan pembelajaran berbasis konvemsional dapat dilihat pada tabel berikut:

Tabel 7. Data Pre Test hasil Belajar Konstruksi Bangunan Kelas Kontrol

\begin{tabular}{lc}
\hline Rata-rata & 64,46 \\
\hline Nilai Tertinggi & 86 \\
\hline Nilai Terendah & 45 \\
\hline Standar Deviasi & 11,61 \\
\hline Varians & 134,792 \\
\hline
\end{tabular}

Berdasarkan data hasil pre test diperoleh dengan jumlah responden 33 siswa, terdapat nilai tertinggi $=86$ dan nilai terendah $=45$ dengan rata-rata $(\mathrm{M})=64,46$ dan standar deviasi $(\mathrm{St})=11,61$. Dengan menggunakan teknik sturges didapatkan banyak kelas 5 dan panjang kelas 9, dan dimulai dengan ujung bawah kelas pertama yaitu 45

Berdasarkan data yang diperoleh pada pre test kelas kontrol, maka dapat diperoleh tingkat kecenderungan pada tabel berikut:

Tabel 8. Data Tingkat Kecendrungan Pre Test hasil Belajar Konstruksi Bangunan Kelas Kontrol

\begin{tabular}{cccl}
\hline $\begin{array}{c}\text { Kelompok } \\
\text { Interval }\end{array}$ & $\begin{array}{c}\text { F. } \\
\text { Absolut }\end{array}$ & $\begin{array}{c}\text { F. } \\
\text { Relatif }\end{array}$ & $\begin{array}{c}\text { Kate } \\
\text { gori }\end{array}$ \\
\hline $75,745<$ & 8 & $24,24 \%$ & Tinggi
\end{tabular}


Pengaruh Media Pembelajaran EXE (Elearning XHTML Editor)

Terhadap Hasil Belajar Konstruksi Bangunan Kompetensi Keahlian Teknik Gambar Bangunan Pada siswa Kelas X SMK Negeri 5 Medan

\begin{tabular}{cccc}
$65,5 \leq x<75,745$ & 10 & $30,30 \%$ & Cukup \\
$55,255 \leq x<65,5$ & 9 & $27,27 \%$ & Kurang \\
$<55,255$ & 6 & $18,18 \%$ & Rendah \\
\hline Jumlah & 33 & $100 \%$ & \\
\hline
\end{tabular}

Berdasarkan perhitungan di atas diperoleh bahwa pre test tes hasil belajar Konstruksi Bangunan pada kelas kontrol mempunyai tingkat kecenderungan yang cukup.

\subsection{Data Post Test Hasil Belajar Konstruksi Bangunan Kelas Esperimen}

Di akhir penelitian pada kedua kelas diberikan instrument test berupa soal pilihan berganda yang berjumlah 22 soal untuk mengetahui hasil belajar siswa setelah diberikan perlakuan.

Berdasarkan test hasil belajar yang diberikan setelah proses pemberian perlakuan, nilai yang diperoleh siswa pada kelas eksperimen yang diajar dengan menggunakan media pembelajaran berbasis elearning dapat dilihat pada tabel berikut:

Tabel 9. Data Post Test hasil Belajar Konstruksi Bangunan Kelas Eskperimen

\begin{tabular}{lc}
\hline Rata-rata & 87,05 \\
\hline Nilai Tertinggi & 95 \\
\hline Nilai Terendah & 73 \\
\hline Standar Deviasi & 6,54 \\
\hline Varians & 42,77 \\
\hline
\end{tabular}

Berdasarkan data hasil Post test diperoleh dengan jumlah responden 33 siswa, terdapat nilai tertinggi $=95$ dan nilai terendah $=73$ dengan rata-rata $(\mathrm{M})=81,13$ dan standar deviasi $(\mathrm{St})=6,54$. Dengan menggunakan teknik sturges didapatkan banyak kelas 5 dan panjang kelas 5, dan dimulai dengan ujung bawah kelas pertama yaitu 73

Berdasarkan data yang diperoleh pada pre test kelas kontrol, maka dapat diperoleh tingkat kecenderungan pada tabel berikut:

Tabel 10. Data Tingkat Kecendrungan Post Test hasil Belajar Konstruksi Bangunan Kelas Eskperimen

\begin{tabular}{cccc}
\hline $\begin{array}{c}\text { Kelompok } \\
\text { Interval }\end{array}$ & $\begin{array}{c}\text { F. } \\
\text { Absolut }\end{array}$ & $\begin{array}{c}\text { F. } \\
\text { Relatif }\end{array}$ & Kategori \\
\hline $89,49<$ & 15 & $36,36 \%$ & Tinggi
\end{tabular}

\begin{tabular}{cccc}
$84 \leq \mathrm{x}<89,49$ & 7 & $12,12 \%$ & Cukup \\
$78,51 \leq \mathrm{x}<84$ & 6 & $30,30 \%$ & Kurang \\
$<78,51$ & 5 & $21,21 \%$ & Rendah \\
\hline Jumlah & 33 & $100 \%$ & \\
\hline
\end{tabular}

Berdasarkan perhitungan di atas diperoleh bahwa pre test tes hasil belajar Konstruksi Bangunan pada kelas kontrol mempunyai tingkat kecenderungan yang tinggi.

\subsection{Data Post Test Hasil Belajar Konstruksi Bangunan Kelas Kontrol}

Berdasarkan test hasil belajar yang diberikan setelah proses pemberian perlakuan, skor yang diperoleh siswa pada kelas kontrol yang diajarkan dengan pembelajaran konvensional dilihat pada tabel berikut:

Tabel 11. Data Post Test hasil Belajar Konstruksi Bangunan Kelas Kontrol

\begin{tabular}{lc}
\hline Rata-rata & 83,06 \\
\hline Nilai Tertinggi & 95 \\
\hline Nilai Terendah & 73 \\
\hline Standar Deviasi & 7,73 \\
\hline Varians & 59,753 \\
\hline
\end{tabular}

Berdasarkan data hasil Post test diperoleh dengan jumlah responden 33 siswa, terdapat nilai tertinggi $=95$ dan nilai terendah $=73$ dengan rata-rata $(\mathrm{M})=83,06$ dan standar deviasi $(\mathrm{St})=7,73$. Dengan menggunakan teknik sturges didapatkan banyak kelas 5 dan panjang kelas 5, dan dimulai dengan ujung bawah kelas pertama yaitu 73 .

Berdasarkan data yang diperoleh pada pre test kelas kontrol, maka dapat diperoleh tingkat kecenderungan pada tabel berikut :

Tabel 12. Data Tingkat Kecendrungan Post Test hasil Belajar Konstruksi Bangunan Kelas Kontrol

\begin{tabular}{cccc}
\hline $\begin{array}{c}\text { Kelompok } \\
\text { Interval }\end{array}$ & $\begin{array}{c}\text { F. } \\
\text { Absolut }\end{array}$ & $\begin{array}{c}\text { F. } \\
\text { Relatif }\end{array}$ & Kategori \\
\hline $89,49<$ & 10 & $30,30 \%$ & Tinggi \\
$84 \leq \mathrm{x}<89,49$ & 6 & $18,18 \%$ & Cukup \\
$78,51 \leq \mathrm{x}<84$ & 9 & $27,27 \%$ & Kurang \\
$<78,51$ & 8 & $24,24 \%$ & Rendah \\
\hline Jumlah & 33 & $100 \%$ & \\
\hline
\end{tabular}

Berdasarkan perhitungan di atas diperoleh bahwa pre test tes hasil belajar Konstruksi 
Bangunan pada kelas kontrol mempunyai tingkat kecenderungan yang tinggi.

\subsection{Uji Persyaratan Analisis} 4.5.1 Uji Normalitas

Secara ringkas hasil uji normalitas dapat dilihat pada tabel berikut:

Tabel 13. Uji Normalitas

\begin{tabular}{cccccc}
\hline Kelas & Data & $\mathbf{N}$ & $\mathbf{L}_{\mathbf{o}}$ & $\mathbf{L}_{\text {tabel }}$ & $\begin{array}{c}\text { Kesim } \\
\text { pulan }\end{array}$ \\
\hline $\begin{array}{c}\text { Eksperi } \\
\text { men } \\
\text { Kontrol }\end{array}$ & $\begin{array}{c}\text { Pre } \\
\text { Test } \\
\text { Pre } \\
\text { Test }\end{array}$ & 33 & 0,1037 & 0,1542 & Normal \\
\hline Kelas & Data & $\mathbf{N}$ & $\mathbf{L}_{\mathbf{o}}$ & $\mathbf{L}_{\text {tabel }}$ & $\begin{array}{c}\text { Kesim } \\
\text { pulan }\end{array}$ \\
\hline $\begin{array}{c}\text { Eksperi } \\
\text { men }\end{array}$ & $\begin{array}{c}\text { Post } \\
\text { Test }\end{array}$ & 33 & 0,1127 & 0,1542 & Normal \\
Kontrol & $\begin{array}{c}\text { Post } \\
\text { Test }\end{array}$ & 33 & 0,1456 & 0,1542 & Normal \\
\hline
\end{tabular}

Berdasarkan tabel, diperoleh $\mathrm{L}_{\mathrm{o}}<\mathrm{L}_{\text {tabel }}$ sehingga dapat disimpulkan data pre test dan Post test pada uji normalitas menunjukkan bahwa data-data nilai hasil belajar siswa dinyatakan memiliki data yang berdistribusi normal.

\subsubsection{Uji Homogenitas}

Secara ringkas hasil uji homogenitas dapat dilihat pada tabel berikut:

Tabel 14. Uji Homogenitas

\begin{tabular}{|c|c|c|c|c|c|}
\hline Kelas & $\mathrm{S}^{2}$ & $\mathbf{N}$ & $\begin{array}{c}\text { Fitun } \\
\mathrm{g}\end{array}$ & $F_{\text {tabel }}$ & $\begin{array}{l}\text { Kesim } \\
\text { pulan }\end{array}$ \\
\hline \multirow{2}{*}{$\begin{array}{l}\text { Kontrol } \\
\text { Eksperi } \\
\text { men }\end{array}$} & 134,792 & 33 & \multirow[b]{2}{*}{1,144} & \multirow[b]{2}{*}{2,313} & \multirow[b]{2}{*}{$\begin{array}{c}\text { Homo } \\
\text { gen }\end{array}$} \\
\hline & 154,256 & 33 & & & \\
\hline Kelas & $\mathrm{S}^{2}$ & $\mathbf{N}$ & $\begin{array}{c}F_{\text {hitun }} \\
\mathrm{g}\end{array}$ & $F_{\text {tabel }}$ & $\begin{array}{l}\text { Kesim } \\
\text { pulan }\end{array}$ \\
\hline $\begin{array}{l}\text { Kontrol } \\
\text { Eksperi } \\
\text { men }\end{array}$ & $\begin{array}{l}83,06 \\
87,05\end{array}$ & $\begin{array}{l}33 \\
33\end{array}$ & 1,048 & 2,313 & $\begin{array}{c}\text { Homo } \\
\text { gen }\end{array}$ \\
\hline
\end{tabular}

Berdasarkan tabel, diperoleh $\mathrm{F}_{\text {hitung }}<\mathrm{F}_{\text {tabel }}$ sehingga dapat disimpulkan bahwa sampel berasal dari populasi yang homogen

\subsection{Pengujian Hipotesis}

Dalam menguji hipotesis digunakan rumus uji-t satu pihak, dengan hipotesis: $\mathrm{H}_{\mathrm{a}}: \mu_{\mathrm{EXE}}>\mu_{\mathrm{C}}$
: Hasil belajar siswa yang diajarkan menggunakan media pembelajaran melalui eXe (eLearning XHTML editor) lebih besar dari pada hasil belajar siswa yang diajarkan menggunakan pembelajaran berbasis konvensional pada siswa kelas X SMK Negeri 5 Medan.

Dengan kriteria pengujiannya adalah $\mathrm{H}_{\mathrm{a}}$ diterima jika $t_{\text {hitung }}>t_{\text {tabel. }}$. Dari lampiran diperoleh:

Kelas eksperimen

$\bar{X}_{1}=87,05 \quad \mathrm{~s}_{1}^{2}=42,771 \quad \mathrm{n}_{1}=33$

Kelas kontrol

$\bar{X}_{2}=83,06 \quad \mathrm{~s}_{2}^{2}=59,753 \quad \mathrm{n}_{2}=33$

Maka, didapat $t_{\text {hitung }}=2,263$

Harga $t_{\text {tabel }}$ dari daftar distribusi dengan $\mathrm{dk}=\mathrm{n}_{1}$ $+\mathrm{n}_{2}-2$ dan dengan $\mathrm{a}=0,05$. Maka didapat $\mathrm{dk}$ $=33+33-2=64$, berada di antara $\mathrm{dk}=60 \mathrm{dan}$ $\mathrm{dk}$ 120. Karena harga $\mathrm{t}_{(0,05)}$ dan $\mathrm{dk}=64$ tidak terdapat dalam distribusi $t$, maka $t_{\text {tabel }}$ dapat diperoleh dengan interpolasi: $t_{\text {tabel }}=1,670$

Maka harga $t_{\text {tabel }}$ pada uji satu pihak sebesar 1,670. Karena harga $t_{\text {hitung }}$ lebih besar dari harga $t_{\text {tabel }}(2,263>1,670)$ atau jauh pada daerah penerimaan $\mathrm{H}_{\mathrm{a}}$, maka $\mathrm{H}_{\mathrm{a}}$ diterima. Dengan kata lain, hasil belajar siswa yang diajarkan dengan menggunakan eXe (elearning XHTML editor) lebih besar dari hasil belajar siswa yang diajarkan dengan pembelajaran berbasis konvensional pada siswa kelas X SMK Negeri 5 Medan.

\section{Kesimpulan, Implikasi dan Saran}

5.1 Kesimpulan

Berdasarkan hasil penelitian yang telah diuraikan pada bab sebelumnya, maka dapat ditarik kesimpulan yaitu hasil belajar Konstruksi Bangunan siswa kelas $X$ Kompetensi Keahlian Teknik Gambar Bangunan SMK Negeri 5 Medan yang diajar dengan pembelajaran eXe (eLearning XHTML editor) lebih unggul dari pada yang diajar dengan melalui pembelajaran konvensional.

\section{2 Implikasi}

Penggunaan media pembelajaran yang tepat akan menciptakan suasana belajar yang lebih baik demi tercapainya hasil belajar yang baik pula. Oleh karena itu, pemilihan media pembelajaran menjadi faktor yang sangat penting dalam merencanakan kegiatan pembelajaran. Dalam hal ini, kegiatan pembelajaran dengan menggunakan media $e X e$ (eLearning XHTML editor) ini sangat efektif 
karena membangkitkan dan menggali potensi siswa di dalam meningkatkan kompetensi menguasaai materi pelajaran Konstruksi Bangunan. Siswa perlu diperkenalkan dengan teknologi sehingga ia bias mengembangkan kreatifitas dengan pemanfaatan teknologi yang ada. Kondisi belajar yang digunakan di SMK Negeri 5 Medan masih menggunakan pembelajaran konvensional sehingga menciptakan suasana belajar yang pasif dan monoton. Proses belajar akan lebih baik jika kita sebagai guru melibatkan siswa dalam kegiataan belajarnya, dan kita tidak lagi sebagai informan tetapi sebagai fasilitator yang membantu siswa untuk menemukan pengetahuan mereka sendiri. Oleh karena itu, ada baiknya diterapkan pembelajaran dengan menggunakan media eXe (eLearning XHTML editor) sesuai dengan teknologi yang ada.

\section{3 Saran}

Berdasarkan hasil analisis data dan kesimpulan yang dikemukakan sebelunya, maka disarankan hal-hal sebagai berikut:

a. Kepala Sekolah dapat menjadikan hasil penelitian sebagai bahan masukan dan referensi dalam peningkatan proses pembelajaran dan mutu pendidikan kejuruan.

b. Guru dapat menerapkan pembelajaran eXe (eLearning XHTML editor) pada kegiatan belajar untuk meningkatkan hasil belajar siswa seperti yang ditunjukkan oleh hasil belajar Konstruksi Bangunan.

c. Siswa dapat meningkatkan hasil belajar siswa dalam mata pelajaran Konstruksi Bangunan khususnya dalam penggunaan pembelajaran eXe (eLearning XHTML editor) sehingga semua siswa dapat menggunakan media berbasis komputer

d. Kepada para peneliti yang ingin mengkaji pengaruh media pembelajaran terhadap hasil belajar, disarankan untuk meneliti media pembelajaran yang lebih unggul untuk meningkatkan hasil belajar siswa.

\section{Daftar Pustaka}

Arikunto, S 2002. Prosedur Penelitian, Suatu Pendekatan Praktek. Jakarta :PT. Rineka Cipta
2006. Prosedur Penelitian Suatu Pendekatan Praktik, Ed Revisi VI, Jakarta: PT Rineka Cipta

Azhar, Arsyad. 2009. Media Pembelajaran. Jakarta:Raja Grafindo Persada

Djamarah dan Zain. 1996. Strategi Belajar Mengajar. Jakarta : PT Rineka Cipta

Gagne, R. M. 1975. Essentials of Learning for I nstruction. New York: Holt, Rinehart and Wiston

Gerlach, D. P. Ely. 1971. Teaching \& Media: Systematic Approach. Second Edition.Boston by V.S. 1980. MA: Allyn and Bacon. Boston by Pears on Education

Hamalik, O. 1986. Media Pendidikan. Bandung: Citra Aditya Bakti

1994. Media Pendidikan. Bandung :Citra Aditya Bakti

2008. Kurikulum dan Pembelajaran.Jakarta: Bumi Aksara

Heinich, R., Molenda, M., And Russels, J.D. 1982. Instructional Media. America Miriam Seda

Munadi, Yudhi. 2008. Media Pembelajaran;Sebuah Pendekatan Baru. Jakarta : Gaung Persada Press

Purwanto. 2010. Evaluasi Hasil Belajar. Yogyakarta: Pustaka Pelajar.

Sabri, Ahmad. 2007. Strategi Belajar Mengajar Micro Teaching. Padang: Quantum Teaching 2010. Strategi Belajar Mengajar dan Micro Teaching. Ciputat: Quantum Teaching Sudjana, Nana. 2001. Penelitian dan Penilaian Pendidikan. Bandung: Sinar Baru

2005. Penilaian Hasil Proses Belajar Mengajar. Bandung : Remaja Rosdakarya.

Rivai. 2002. Media Pendidikan. Jakarta: Balai Pustaka.

Sugiyono. 2010. Metode Penelitian Kuantitatif, Kualitatif \& RND. Bandung: Alfabeta.

Sunaryo, Soenarto. 2009. Multimedia Interaktif dan Implementasinya. Makalah Pelati Meltimedia Pembelajaran. P3AI. Yogyakarta : UNY 